\title{
Developing Central and Eastern Europe As a Hub For Global Entrepreneurship: Budapest and Prague As Cases in Point
}

\author{
Bala Mulloth", Andreas Antonopoulos**
}

It can be stated that Central and Eastern Europe is fast becoming a hub for entrepreneurship and innovation. There appears to be a robust ecosystem where universities/business schools, venture capitalists and non-profit organizations are working together to promote entrepreneurship at several levels. This paper seeks to explore the entrepreneurial ecosystems prevalent in 2 prominent central and eastern European capital cities - Budapest and Prague, often referred to as the "Entrepreneurial corridor" of the CEE due to the straight line they represent geographically, cutting across the CEE region and being the main centers of entrepreneurial activity in this region. In the past few years several startup success stories have emerged across these cities. These include AVG and Avast from the Czech Republic and Prezi, LogMeIn, and Ustream from Hungary.

To study the entrepreneurial ecosystems, we employ the case study methodology and interview key stakeholders at prominent business schools and venture capital firms in the region in addition to the founders of new businesses. We seek to understand the challenges faced by new businesses in these regions and how the regional ecosystems could best assist in the start-up and development of new ventures. We conclude by presenting key recommendations on how best to strengthen the region as a global entrepreneurial hub, to bring valuable ideas to the market with support from university management, policy makers as well as the region's burgeoning entrepreneurial ecosystem of angel investors, venture capitalists and business incubators.

Keywords: global entrepreneurship, hubs of innovation, entrepreneurial ecosystems, Central and Eastern Europe.

Submitted: 30.06.2014 | Accepted: 31.08.2014

\section{Rozwój Europy Środkowo-Wschodniej jako centrum globalnej przedsiębiorczości - przykłady Budapesztu i Pragi}

Europę Środkowo-Wschodnia można uznać za szybko rozwijające się centrum przedsiębiorczości i innowacji. Istnieje tam rozbudowany ekosystem, $w$ którym wspótpracuja uniwersytety/szkoty biznesu, inwestorzy kapitału wysokiego ryzyka i organizacje non-profit, dażac do wsparcia przedsiębiorczości na wielu poziomach. Artykut ma na celu przeanalizowanie ekosystemów przedsiębiorczości występujacych $w$ dwóch znaczacych stolicach Europy ŚrodkowoWschodniej - Budapeszcie i Pradze, które ze względu na przebiegajaca przez nie prosta linię geograficzna, przecinająca te część Europy, sa często określane mianem „korytarza przedsię-

\footnotetext{
Bala Mulloth - Assistant Professor of Entrepreneurship and Innovation Management at Central European University (CEU) Business School and Faculty Director of CEU InnovationsLab. Adres do korespondencji: bmulloth@gmail.com.

** Andreas Antonopoulos - Rector and Professor of Entrepreneurship at the University of New York in Prague.
} 
biorczości” Europy Środkowo-Wschodniej i stanowia główne ośrodki dziatalności gospodarczej w tym regionie. W ciagu ostatnich kilku lat w tych miastach powstato szereg nowych firm, które odniosty sukces. Należa do nich AVG i Avast z Czech i Prezi, LogMeIn oraz Ustream $z$ Węgier.

W badaniu ekosystemów przedsiębiorczości zastosowaliśmy metodę studium przypadku i przeprowadziliśmy wywiady z kluczowymi interesariuszami z czotowych szkót biznesu i przedsiębiorstw venture capital $w$ regionie, a także z zatożycielami nowych firm. Staramy się określić wyzwania, przed którymi stoja nowe firmy w tych regionach oraz sposób, w jaki ekosystemy regionalne mogtyby najlepiej pomóc $w$ rozruchu i rozwoju nowych przedsięwzięć. Artykut kończa główne zalecenia dotyczace najlepszych sposobów umocnienia regionu jako globalnego centrum przedsiębiorczości, wprowadzenia cennych pomystów na rynek przy wsparciu kadry kierowniczej uczelni, decydentów, jak również rozkwitającego w regionie ekosystemu przedsiębiorczości obejmującego tzw. anioly biznesu, inwestorów kapitału wysokiego ryzyka i inkubatory przedsiębiorczości.

Słowa kluczowe; globalna przedsiębiorczość, centra innowacji, ekosystemy przedsiębiorczości, Europa Srodkowo-Wschodnia.

Nadesłany: 30.06.2014 | Zaakceptowany do druku: 31.08.2014

JEL: M13, L24, L26

\section{Introduction}

Entrepreneurship is expanding its reach and scope. It is local and increasingly global. No longer is it a phenomenon dominated by western capitalist nations and top Ivy League universities such as Massachusetts Institute of Technology (MIT), Harvard University and Stanford University, among others. As will be described in the subsequent sections of this paper, entrepreneurship is not just alive but indeed thriving in Central and Eastern Europe (CEE).

CEE consistently ranks at the top of the world rankings in educational achievement in math, science and technology. In 2013, 16 out of the 24 finalists of Google's annual Code Jam programming competition were from Central and Eastern Europe according to Bloomberg (Szabo, 2013). This region also accounted for 8 of the 13 winners at this year's ACM International Collegiate Programming Contest (Khrennikov and Wong 2013). Capital inflow to the region is improving thanks largely to the European Union initiative such as the JEREMIE program developed in cooperation with the European Commission that offers CEE countries such as Hungary and Bulgaria the opportunity to finance startups by means of equity, loans or guarantees.
The paper is organized as follows. We begin with an overview of the relevant research literature in the field. We then present the research design and methodology employed. Snapshots of the Budapest Entrepreneurial Ecosystem and the Prague Entrepreneurial Ecosystem are then presented. Later we provide a discussion of the various entrepreneurial ecosystems with respect to the role they play in developing CEE as a hub for global entrepreneurship and present our conclusions on how entrepreneurship in CEE can be strengthened even further.

\section{Literature Overview}

Entrepreneurship is now increasingly recognized as an essential part of the modern technological innovation process, and entrepreneurs are found throughout the globe (Wooldridge, 2009). Some even refer to the need for an entrepreneurial society (Schramm, 2006). In such a scenario, entrepreneurs figure as important players. They maintain an advantage through their flexibility, freedom and risk everything ambition to find the path back to prosperity in a rapidly changing, technology driven global economy (Hayes and Malone 2009). As Karnani (2007) put it, "An entrepreneur is 
a person of vision and creativity who converts a new idea into a successful innovation, into a new business model."

It would be beneficial for local high-tech startups to be able to detect, absorb, and use the scientific research being produced by local constituencies in the regions they operate in (Colombo, D'Adda and Piva, 2010). It must be noted that new ventures have no track record and need to assemble a range of different input factors into an operating organization. This new organization needs to establish operating routines, secure affordable inputs from suppliers, and develop a customer base willing to purchase its products/services. This takes time with steep learning curves against an organization's limited resources. Brannon et al (2013) noted that new organizations are imprinted with characteristics that fit the specific environment in which they were founded. The internal and external characteristics at founding have long-term effects on the development, survival and performance of new ventures (Ganco and Agarwal, 2009).

Establishing a new venture requires access to various resources such as financial capital, physical assets, technological resources, human capital, and organizational resources. Intangible 'soft' resources are often more useful than tangible resources in the early stage of venture development (Lichtenstein and Brush, 2001). Successful creation of a new venture depends on the ability to both assemble and organize resources (Brush, Manolova and Edelman, 2008). In addition to the resources needed to develop the technology and build the organization, new ventures need to build legitimacy in the relationship with all their operating partners (Delmar and Shane, 2004; Zimmerman and Zeitz, 2002). As a result, new ventures greatly benefit from the locational advantage of the cluster where the startup is located (Keeble and Wilkinson, 1999). The role of the local environment is particularly important for young startups because these firms are usually developed by teams where several persons play an active championing role (Vanaelst et all, 2006). Support from champions such as colleague scientists, university managers, technology transfer office staff, and people in the external network of the university are often critical, particularly in early stages (Rasmussen, 2011).

It is also necessary to consider the region's potential, the companies, and which dynamics are present in the region. Such an approach needs to be able to incorporate holistic approaches to collective learning, competitiveness, sustainability and cohesion. Much has been written about knowledge and learning and its role in social and economic development, and specifically in the consequences of the development of specific places (Lever, 2002). Consequently, there are places that are economically successful which claim to exhibit the characteristics of learning regions or learning cities (Keeble and Wilkinson, 1999), and many city and regional authorities have set their sights on strategies to develop knowledge-based activities, or to create learning communities (Longworth, 2006). Such an approach encourages new ventures to take more risks since the ecosystem perceives new ventures as a collective learning experience. In case of a new venture failure, the probability of its absorption by an existing venture or institution in the ecosystem is quite high. In fact, the ecosystem recognizes failure as a valuable learning opportunity (Murphy, 2010).

Recent scholarship on entrepreneurship has also tended to emphasize the efficacy of entrepreneurship in a modern network economy, i.e., an economy characterized by, for example, interwoven global networks (Nijkamp, 2003). According to this line of thinking, entrepreneurship, which tends to seek new combinations or recombinations, can fit in well in a network economy. Paul Romer (Romer, Jaffe and Trajtenberg, 2005) of Stanford University has argued that "Economic growth occurs whenever people take resources and rearrange them in ways that are more valuable." In such a business environment, where speed, adaptation, flexibility and somewhat fluid restructuring are often needed, a successful entrepreneurial venture is one that is responsive and adaptable to changing settings. As a recent overview of entrepreneurship noted, "The entrepreneur is thus back on the scene. But these strategies may be entirely different from those in the past, as the institutional and technological environment of entrepreneurship has changed drastically" (Nijkamp, 2003). 


\section{Research Design and Data Collection}

The research approach used for this paper is qualitative in nature. We employ an inductive approach where the interviewees were given much space in order to provide their knowledge. Following the theoretical sampling of the Budapest and Prague entrepreneurial ecosystems, we will build on the suggestive arguments that multiple cases create more robust theory grounded in varied empirical evidence (Eisenhardt and Graebner, 2007). Grounded theory could appear in various forms. "Grounded theory could be presented either as a wellcodified set of propositions or in a running theoretical discussion, using conceptual categories and their properties" (Glaser and Strauss, 1967). Strauss and Corbin acknowledge the importance of a multiplicity of perspectives and "truths" (Strauss, 1987; Strauss and Corbin, 1990) and as such have "extended and emphasized the range of theoretically sensitizing concepts that must be attended to in the analysis of human action/interaction" (MacDonald, 2001). Following the work of other scholars (Leonard-Barton, 1990; Gibbert, Ruigrok and Wicki, 2008), we carried our interviews in close interaction with practitioners who deal closely with the development of entrepreneurial ecosystems in their respective cites. In choosing an interpretive paradigm (Gioia and Pitre, 1990), we aimed to gain a deeper understanding of a phenomenon through understanding the interpretations of that phenomenon from those experiencing it (Shah and Corley, 2006). Following the case-study methodology (Yin, 2003), we applied such methods as in-depth individual, semi-structured interviews (interviews which leave room for adjustments during the interview process) with keys members of the organizations (those responsible for their management, governance and administration), entrepreneurial teams and others. Following Maxwell (Maxwell, 2004), before locking onto interview questions, we attempted to get a good sense of what my theoretical and methodological commitments and options were and their implications for our questions.

Additionally, we also performed extensive primary and secondary historical research and analysis. We accessed primary and secondary archival sources such as news reports, governmental reports, industry reports issued by consulting firms, as well as coverage of industry developments in the media and industry trade presses.

\section{Budapest Entrepreneurial Ecosystem}

I believe there is great momentum and a critical mass of experience coming from success stories like LogMeIn, Ustream and Prezi that will put Budapest among the global entrepreneurial tech hubs

Peter Arvai,

Co-founder and CEO of Prezi.com

Besides a good number of World Heritage Sites, Budapest is one of the most attractive metropolitan cities in Europe. It has a young, burgeoning startup scene in a city where the cost of living is still remarkably affordable and much lower than in Western Europe. At the same time, the educational system in Hungary is of a very high quality with a number of esteemed universities such as the Central European University (CEU) Business School founded by George Soros, the Budapest University of Technology and Economics, in Hungarian abbreviated as BME ("the local MIT"), Corvinus University and Semmelweis University, among others. Little surprise then that Hungary is home to powerful and world famous inventions such as the personal computer, ballpoint pen, Rubik's cube, insulin and the Pulitzer Prize to name just a few.

The mix of low living costs and great human talent provides the necessary ingredients for Budapest to be the center of a fast growing and flourishing startup ecosystem in CEE. Further, the Jeremie I-IV funds (HUF 130 billion) received from the European Union for new venture creation, a previously ignored area within the Hungarian entrepreneurship ecosystem, provide a great incentive and encouragement to pursue entrepreneurship and innovation at the highest level. For startups specifically, the European Investment Fund (EIF) funded venture capital is available in abundance via the JEREMIE program.

In addition to Hungary's traditional strength in the pharma, biotech and medical fields, within Budapest, the majority of the startup success stories so far seem to 
be centered on Information Technology and Software as Service (SAAS) areas. There also appears to be increased activity in the mobile development space as well as in the finance and payment processing fields. There are also a number of successful ideas being implemented with a local touch, like indulj.be (based on Kickstarter) and a number of Groupon clones.

\section{Select Examples of Budapest Based Startups}

Prezi: Officially launched in April 2009, and with offices in Budapest and San Francisco, Prezi offers a presentation software alternative to Microsoft PowerPoint, a more traditional tool for the creation of presentations that hold text, images, and animations. As of May 2014, Prezi had more than 40 million users from over 190 countries, fostering a community of over 100 million prezis around the world.

LogMeIn: LogMeIn, Inc. is a public company that provides software as service based remote connectivity, collaboration, and support solutions to businesses and consumers.

Usteam: The company was founded in 2007 with a vision to bring live online broadcasting technology mainstream. Today it is a leading video technology platform for live business communications, powered by the company's Ustream Cloud Platform.

Mixgar: Mixgar is an interactive social jukebox that streams music based on guests preferences and votes for the most liked song at the current venue. The company was launched as part of the incubation program of Digital Natives, an agile tech development company based in Budapest, Hungary.

\section{Entrepreneurship Resources and Support}

Budapest seems to have an emerging startup ecosystem of business incubators, co-working spaces, funding sources and events available for entrepreneurs. Business Incubators such as the CEU InnovationsLab $^{1}$ serves as a bridge between academia and business in Budapest and the Central and Eastern European region. The Lab provides an environment where university students and faculty can be startup founders and learn from fellow entrepreneurs and mentors as they grow their businesses. Kitchen Budapest (KIBU) is a space where founders experiment with ideas in the intersection of design, technology, art and business. Founded in 2007 and powered by Telekom, KIBU is a multidisciplinary team of designers, technologists, artists, researchers and entrepreneurs working in a collaborative environment to create value and push ideas forward. Colabs is another Budapest based startup center and tech hub that seeks to work with promising startups by providing professional incubation services such as mentoring, providing contacts and assisting with team building, strategic planning and fundraising.

Additionally, there are several annual events and conferences that provide opportunities for would-be entrepreneurs to explore and access their entrepreneurial interests. Some of the main resource offerings are as indicated in Table 1 below:

Budapest also possesses a thriving professional networking scene and weekly, biweekly and monthly gatherings organized

Table 1. Annual events and conferences

\begin{tabular}{|l|l|}
\hline \multicolumn{1}{|c|}{ Conference Name } & \multicolumn{1}{c|}{ Focus Areas } \\
\hline Startup Underground & Promotion and development of local CEE startups \\
\hline Smartmobil & Mobile trends and technologies \\
\hline Barcamp Budapest & Web based/digital products and services \\
\hline Hungarian Innovation Tech Show & Technology based companies \\
\hline Startup Sauna Budapest & Early stage startup accelerator \\
\hline Seedcamp Budapest & Venture accelerator \\
\hline Colabs Startup School & Technology based companies \\
\hline
\end{tabular}

Wydział Zarządzania UW ～DOI 10.7172/1733-9758.2014.17.1 
Table 2. Professional Networking Events

\begin{tabular}{|l|l|}
\hline \multicolumn{1}{|c|}{ Event } & \multicolumn{1}{c|}{ Key Purpose } \\
\hline Budapest Business Meetup & Monthly theme-based Business networking \\
\hline International Geek-together & $\begin{array}{l}\text { To bring together expats who are interested in technology relat- } \\
\text { ed service offerings }\end{array}$ \\
\hline Mobile Weekend & Bringing together mobile technology enthusiasts over a weekend \\
\hline New Tech Meetup & Help find link-minded technology professionals \\
\hline Startup Budapest & Business development for startups \\
\hline Startup Flyer & Connecting talented people, businesses, and capital \\
\hline Startuprise & Business networking event \\
\hline Startup Weekend Budapest & Budapest version of the popular Startup Weekend series \\
\hline
\end{tabular}

in a continuous and ongoing manner. Some of the more popular and well-attended events are summarized in Table 2 below:

\section{Funding Resources}

There are several initiatives in Budapest that connect entrepreneurs to the funding they need to grow their business. As an example, Primus Capital is an international fund that seeks to accelerate the growth of early stage companies by providing them access to venture capital funding, development advice and access to international clients, partners and investors. The fund is based in Budapest, Vienna and Munich and works in partnership with local entrepreneurs to create value for the region in which they operate.

Another important funding agency is Euroventures, one of the oldest and most established private equity and venture capital firms in Central Europe. The organization is a founding member of the Hungarian Venture Capital Association and complies with the conduct, governing principles and valuation/reporting guidelines of the European Private Equity \& Venture Capital Association. In 2009, Euroventures won the mandate to manage the Co-Investment Fund of the JEREMIE Program that resulted in it starting the Euroventures IV Venture Capital Fund, with HUF 4 billion of shared capital to invest in early-stage companies. Apart from this, there is also Day One Capital, a venture capital fund that targets companies in the IT, telecommunications, energy, biotech and finance sectors with investments between $€ 200$ $400 \mathrm{k}$. There are also periodic events such as the Budapest Business Angel Club and Blind Investment that showcase local startups to potential investors.

\section{Web Based Resources and Tech Blogs}

Entrepreneurs in Hungary can take advantage of several digital resources and blogs that offer advice on starting new ventures, technology trends, entrepreneur's dilemmas, startup data and statistics, etc. Table 3 below summarizes some of more popular web based resources that are available.

Table 3. Digital Resources

\begin{tabular}{|l|l|}
\hline \multicolumn{1}{|c|}{ Resource } & \multicolumn{1}{c|}{ Key Purpose } \\
\hline Insider Blog & Tech blog focusing on the local startup ecosystem \\
\hline Silicon Goulash & English language blog covering local tech startups \\
\hline Startup Cafe & Blog covering technology startups \\
\hline Startupdate & Blog providing advice on starting new businesses \\
\hline Startups.hu & Database of Hungarian tech startups \\
\hline
\end{tabular}




\section{Prague Entrepreneurial Ecosystem}

The Czech Republic is considered to be the most developed and stable country and market in the CEE region and Prague in particular is the most advanced of the regional capitals in terms of attracted investment, GDP and FDI per capita and also a regional center for covering the wider $\mathrm{CEE}$ region. It has therefore attracted more private equity and venture capital money than any other CEE capital, much of which has a regional rather than a Czech only investment scope. The European Union Jeremie I-IV funds as well as government schemes to support entrepreneurship are supporting the Prague ecosystem, as well as the very large number of international citizens (proportional to the population) who reside in Prague compared to other regional capitals. The latter in particular seem to be particularly prone to entrepreneurial activities making Prague an international rather than a Czech ecosystem. The beauty of the city often considered the most attractive in the CEE region, attested by the highest number of tourists compared to all other European capital, creates a lot of this attraction as well. The downside of all this attention is that costs and salaries in Prague are higher than in the other regional capitals and the other neighboring countries. However, costs are still reasonably lower than in most Western European major cities with significant entrepreneurial activity.

The education system is one of the other key attractions of the entrepreneurial ecosystem in Prague. Beyond world class institutions such as Charles University, Czech Technical University in Prague (CVUT) and the University of Economics, Prague (VSE), Prague has some leading international universities like the University of New York in Prague (UNYP), the main American education programs provider in the Czech Republic attracting students from over 60 different countries capitalizing on its brand recognition and on the attraction of Prague as an international studies destination. The educational sector is churning out a steady supply of talent, primarily from CVUT, which is the main technical university, and from UNYP, which is leading in business studies and is offering an MBA in Entrepreneurship. Both of these institutions have Entrepreneurship Centers that have a co-operation agreement between them and run joint training programs.

The Prague startup scene can be broadly divided into two large periods since the emergence of a market economy in the early 90s. The first phase covering the period until 2007/2008 saw entrepreneurial activity in the low growth SME section that built the backbone of the current market economy with a few notable big successes of charismatic individuals with conviction that resulted in world-class companies such as AVG, Seznam and Avast. From 2008 onwards the global financial crisis has accelerated an interest in entrepreneurial activity for young talent (which was brewing anyway) and has exploded the entrepreneurial footprint in terms of both the participation (talent entering this space) and the support (ecosystem and access to capital).

In Prague most of the startup success stories seem to have a strong tech based angle, as is the case of Budapest. There is also plenty of online retail, tech $\mathrm{B} 2 \mathrm{~B}$ and mobile applications startup players while biotechnology also seems to be attracting increasing attention. Clones of successful western companies that could serve the local market have not been absent and several have been tremendously successful (such as seznam.cz, slevomat.cz and Alza.cz).

\section{Examples of Prague Based Startups}

Seznam: Officially launched in 1996 and achieving success in becoming the leading internet company in Prague, reaching $\$ 500 \mathrm{M}$ turnover in the end of the previous decade, and gaining a household name, was one of the first startup success cases in Prague inspiring a whole generation of new Czech entrepreneurs.

AVG: Founded in the early 90s, this is the most iconic of all Czech startups from the 90 s with a great global success story for the Czech ecosystem. It is a globally recognizable software security brand with almost 200 million active users around the world and a \$1billion + valuation today.

Alza: The largest online retailer in the Czech Republic growing to a $\$ 90 \mathrm{M}$ valuation in less than 5 years.

GoodData: One of the most successful Czech big data analytics companies founded in 2007 which has raised \$53M to date with offices in Prague and San Francisco. It was founded by Roman Stanek, a serial entrepreneur who had founded 
Netbeans in 1997 that he later sold to Sun Microsystems in 1999.

SocialBakers: One of best known success stories in the last couple of years in the Czech Republic is this social media analytics platform. Launched in 2009, it has grown to employ over 250 employees, with customers in more than 100 countries by the end of 2013.

\section{Entrepreneurship Resources and Support}

Prague has developed a very sizeable and supportive ecosystem for aspiring entrepreneurs in the last 5 years. It has the largest incubator/accelerator presence among the CEE capital cities and it was chosen to be the base of Wayra, the Telefonica funded global incubator/accelerator/academy, for the whole CEE region. Business incubators at universities such as the UNYP Entrepreneurship Lab and the CVUT Innovacentrum are also adding firepower to this segment. Co-working spaces have mushroomed and are providing the breeding ground for startups in making funds available through the incubators, the professional Angel networks. Moreover, the resident Venture Capital firms are one of the best in the region.

There are several other incubators, accelerators and co-working spaces as summarized in Table 4 and Table 5 below that provide startup services in Prague.

Table 4. Incubators/Accelerators in Prague

\begin{tabular}{|l|l|}
\hline Incubator/Accelerator & \multicolumn{1}{|c|}{ Key Characteristics } \\
\hline Wayra & $\begin{array}{l}\text { Largest and best funded incubator (Telefonica supported) based in } \\
\text { Prague and covering the entire CEE }\end{array}$ \\
\hline Start-up Yard & The most established Czech accelerator investing in early stage startups \\
\hline Node 5 & $\begin{array}{l}\text { Established Czech incubator/accelerator that also provides co-working } \\
\text { services }\end{array}$ \\
\hline Innovacentrum & CVUT supported University Incubator \\
\hline $\begin{array}{l}\text { UNYP } \\
\text { Entrepreneurship Lab }\end{array}$ & $\begin{array}{l}\text { Business incubation support services for graduates of UNYP who } \\
\text { launch new startups }\end{array}$ \\
\hline Czech Accelerator & $\begin{array}{l}\text { Government supported accelerator program supporting 20-30 Czech } \\
\text { startups every year }\end{array}$ \\
\hline Czech Innovace & A corporate supported Czech Innovation program \\
\hline
\end{tabular}

Table 5. Co-working spaces in Prague

\begin{tabular}{|l|l|}
\hline \multicolumn{1}{|c|}{ Name } & \multicolumn{1}{c|}{ Key Characteristics } \\
\hline Tech Square & Large co-working spaces closely co-operating with Startup Yard \\
\hline The Hub & Part of the "international chain" started in London in 2005 \\
\hline Creative Gate & Emphasis on collaboration opportunities for participants \\
\hline Atelier Pexeso & In-house daycare center for moms with young kids \\
\hline Locus Workspace & Strong focus on the English speaking community \\
\hline Erasvet & Co-working space for startups \\
\hline DeskRoom & Well located in the downtown area \\
\hline C3 & $\begin{array}{l}\text { Professional services for individuals and mobile workers. Downtown } \\
\text { location. }\end{array}$ \\
\hline Business Place & Short term office space needs \\
\hline TheWorks & With a strong focus on organizing relevant events \\
\hline WebHub & For freelancers \\
\hline Green Office Prague & Downtown co-working space \\
\hline
\end{tabular}


Table 6. Annual events and conferences

\begin{tabular}{|l|l|}
\hline \multicolumn{1}{|c|}{ Conference Name } & \multicolumn{1}{c|}{ Focus Areas } \\
\hline Eclub & Entrepreneurship summer camps \\
\hline StarupCamp Praha & Startup conference \\
\hline WebExpo Prague & Web innovation and web startups \\
\hline Global entrepreneurship week & Entrepreneurship week organized by the Kauffman foundation \\
\hline NapadRoku & Startup competition \\
\hline Seedcamp Prague & Venture accelerator \\
\hline
\end{tabular}

Prague offers several annual events and conferences that provide opportunities for would-be entrepreneurs to explore and access their entrepreneurial interests. Some of the main resource offerings are as indicated in Table 6 below:

\section{Monthly Networking Events}

Additionally, Prague also offers an impressive array of professional networking events and meetups as summarized in Table 7 below.

\section{Funding Resources}

Being a fairly established and mature entrepreneurial ecosystem, there are several funding agencies available for young startups to consider. In addition to the ones listed in Table 8 below, the Czech Republic, due to its position, perceived stability and perceived advanced status compared to other CEE peers, is attracting direct investment attention from VCs based in Berlin, London and some other EU major cities.

Table 7. Professional Networking Events

\begin{tabular}{|l|l|}
\hline \multicolumn{1}{|c|}{ Event } & \multicolumn{1}{c|}{ Key Purpose } \\
\hline Prague Entrepreneurs Meetup & Focus on English speaking Prague based entrepreneurs \\
\hline Czech Tuesdays & Business Networking \\
\hline International Geek-together & $\begin{array}{l}\text { To bring together expats who are interested in technology } \\
\text { related service offerings }\end{array}$ \\
\hline
\end{tabular}

Table 8. Funding Resources

\begin{tabular}{|l|l|}
\hline \multicolumn{1}{|c|}{ Agency Name } & \multicolumn{1}{c|}{ Focus Area } \\
\hline Startup Yard & Early stage \$10K-30K investments \\
\hline Wayra & Early stage EUR 40K investments \\
\hline Venture Growth Partners & \$20K-\$50K Angel Investments \\
\hline Business Angels Czech & Intermediaries for angel investments \\
\hline Credo Ventures & Seed Investment VC \$300K + \\
\hline 3TS Capital & Growth Investment VC for \$1M+ tech investment \\
\hline Enterprise Investors & Growth Investments \$1.5M+ \\
\hline Gimv & Growth and expansion capital \$2M+ \\
\hline
\end{tabular}

Wydział Zarządzania UW ～DOI 10.7172/1733-9758.2014.17.1 


\section{Web Based Resources and Tech Blogs}

There are several digital resources and blogs that offer advice on starting new ventures, technology trends, entrepreneur's dilemmas, startup data and statistics, etc. Table 9 below summarizes some of more popular web based resources that are available.
Successful startups such as Prezi and Ustream in Budapest and AVG and Alza in the Czech Republic are leading the way for spurring entrepreneurship in the region by creating great role models for other local entrepreneurs in the region to emulate. There seems to be an ever-increasing array of support services, business incubators and accelerators as well as funding agencies

Table 9. Digital Resources

\begin{tabular}{|l|l|}
\hline \multicolumn{1}{|c|}{ Resource } & \multicolumn{1}{c|}{ Key Purpose } \\
\hline Global startups & Global startup directory \\
\hline tyinternety.cz & Entrepreneurship portal \\
\hline Info.cz & Czech internet info and entrepreneurship updates portal \\
\hline CzechCrunch & Czech startup news site \\
\hline Bizit.cz & IT updates portal \\
\hline StartupJobs & A portal with job opportunities with Czech startups \\
\hline Czech Startup Digest & $\begin{array}{l}\text { Collection of entrepreneurship related events taking place in the } \\
\text { Czech Republic }\end{array}$ \\
\hline
\end{tabular}

\section{Discussion and Conclusion}

Recognizing that entrepreneurial capabilities represent one of the highest forms of value creation in a knowledge-driven economy, especially for small countries in the CEE, Budapest and Prague appear to have embraced innovation and entrepreneurship as one of their top priorities. They seem to be vying for entrepreneurial clusters and are attempting to create an array of policies and incentives to jumpstart and nourish entrepreneurial activities. As a result, several new and exciting initiatives have been launched in these regions to build the right environment to create a hub for global entrepreneurship.

It must be stated that startups in Central and Eastern Europe have a distinctive advantage due to its unique and central global location, access to high quality tech talent and relatively low costs. Further, the entrepreneurial ecosystem in CEE seems to understand that innovation and entrepreneurship are increasingly sought after and nurtured, including in the emerging world, where "reverse innovation" flourishes and where innovative thinking and acting are required for growth and prosperity. available in the region to create a healthy ecosystem for entrepreneurship to thrive. That being said, CEE needs more successful business exits, and more serial entrepreneurs taking a proactive role as investors or mentors to new startups.

Popular startup events such as Seedcamp and the Startup Sauna are going a long way in putting CEE in the global entrepreneurship map by making it a relevant and exciting place for audiences from all over the world to attend. Such events also help provide more exposure to the local aspiring entrepreneurs who may be too conservative and risk averse to venture out on their own. Further, local business meetups and networking events are providing excellent and much needed networking opportunities for entrepreneurs both among themselves and also with the local and regional business and investment community. There appear to be increasing calls for entrepreneurial activities for creating jobs, improving the competitiveness of the region, and attracting as well as retaining human talent. One aspect in which both Budapest and Prague could both improve is to better connect and provide more incentive for cooperation between the various 
hubs that bridge entrepreneurs with investors, clients, mentors and advisors.

Further, it is important to create an ecosystem that encourages successful entrepreneurs to give back to the community either by providing mentoring services or by taking a hands-on role by working closely with venture capitalists who may not necessarily have the required experience or entrepreneurship knowledge and background to invest in the right companies. Finally, while these economies have advanced in the provision of entrepreneurial support services and funding, additional regulatory reforms can help attract investment and encourage entrepreneurship even further.

\section{Note}

1 CEU InnovationsLab is a flagship initiative of Central European Business School's Institute for Entrepreneurship and Innovation, which was established in November 2011 with a grant from philanthropist George Soros. They actively carry out the Institute's dedication to creating economic opportunity in Hungary and the Central and Eastern European region by nurturing a culture of entrepreneurship and linking academia and business.

\section{References}

Brannon, D.L., Wiklund, J. and Haynie, J.M. (2013). The varying effects of family relationships in entrepreneurial teams. Entrepreneurship Theory and Practice, 37(1).

Brush, C.G., Manolova, T.S. and Edelman, L.F. (2008). Properties of emerging organizations: An empirical test. Journal of Business Venturing, 23, 547-566.

Colombo, M.G., D'Adda, D. and Piva, E. (2010). The contribution of university research to the growth of academic start-ups: an empirical analysis. Journal of Technology Transfer, 35, 113-140.

Delmar, F. and Shane, S. (2004). Legitimating first: organizing activities and the survival of new ventures. Journal of Business Venturing, 19, 385-410.

Eisenhardt, K.M. and Graebner, M.E. (2007). Theory building from case studies: Opportunities and challenges. Academy of Management Journal, 50(1), 25-32.

Ganco, M. and Agarwal, R. (2009). Performance differentials between diversifying entrants and entrepreneurial start-ups: A complexity approach. Academy of Management Review, 34(2), 228-252.

Gibbert, M., Ruigrok, W. and Wicki, B. (2008). What passes as a rigorous case study. Strategic Management Journal, 29(13), 1465-1474.
Gioia, D.A. and Pitre, E. (1990). Multi-paradigm perspectives in theory building. Academy of Management Review, 15(4), 584-602.

Glaser, B. and Strauss, A. (1967). The Discovery of Grounded Theory: Strategies for Qualitative Research. Chicago: Aldine Publishing Company.

Hayes, T. and Malone, M. (2009). Entrepreneurs can lead us out of the crisis. Wall Street Journal. Retrieved from: http://online.wsi.com/article/ SB123544318435655825.html?mod=loomia\&loomia _si=t0:a16:g2:r2:c0.263254:b0 (23.02.09).

Karnani, A. (2007). The Mirage of Marketing to the Bottom of the Pyramid: How the Private Sector can help alleviate poverty. California Management Review, 49(4), summer.

Keeble, D. and Wilkinson, F. (1999). Collective learning and knowledge development in the evolution of regional clusters of high technology SMEs in Europe. Regional studies, 33(4), 295-303.

Khrennikov, I. and Wong K. (2013). Ex-Soviet Programmers Take On India in \$48 Billion Market. GlobalTech. Retrieved from: http://www.bloomberg. com/news/2013-09-16/ex-soviet-programmers-takeon-india-in-48-billion-market.html (22.04.14).

Leonard-Barton, D.A. (1990). A Dual Methodology for Case Studies: Synergistic Use of a Longitudinal Single Site with Replicated Multiple Sites. Organization Science, 1(3), 1-19.

Lever, W. F. (2002). Correlating the knowledgebase of cities with economic growth. Urban studies, 39(5-6), 859-870.

Lichtenstein, B.M.B. and Brush, C.G. (2001). How Do „Resource Bundles” Develop and Change in New Ventures? A Dynamic Model and Longitudinal Exploration. Entrepreneurship Theory and Practice, 25, 37-58.

Longworth, N. (2006). Learning cities, learning regions, learning communities: lifelong learning and local government. London: Routledge.

MacDonald, M. (2001). Finding a critical perspective in grounded theory. In: R. Schreiber an P.N. Stern (eds.), Using grounded theory in nursing (pp. 113-158). New York: Springer.

Maxwell, J. (2004). Qualitative Research Design: An interactive approach. Thousand Oaks, CA: Sage Publications, Inc., 2nd edition.

Murphy, J. (2010). Turning around failing organizations: Insights for educational leaders. Journal of Educational Change, 11(2), 157-176.

Nijkamp, P. (2003). Entrepreneurship in a modern network economy. Regional Studies, 37(4), 395-5405.

Rasmussen, E. (2011). Understanding academic entrepreneurship: Exploring the emergence of university spin-off ventures using process theories. International Small Business Journal, 29, 448-471. 
Romer, P., Jaffe, A. and Trajtenberg, M. (2005). Patents, Citations, and Innovations: $A$ Window on the Knowledge Economy. Cambridge, MA: MIT Press.

Schramm, C. (2006). The Entrepreneurial Imperative. HarperBusiness.

Shah, S.K. and Corley, K.G. (2006). Building better theory by bridging the quantitative-qualitative divide. J Manage Stud, 43, 1821-1835.

Strauss, A. (1987). Qualitative analysis for social scientists. Cambridge, UK: Cambridge University Press.

Strauss, A. and Corbin, J. (1990). Basics of qualitative research: Grounded theory procedures and techniques. Newbury Park, CA: Sage.

Szabo, B. (2013). How Central Eastern Europe Is Transforming From Outsourcing To A Real Tech Hub. Forbes. Retrieved from: http://www.forbes. com/sites/ciocentral/2013/10/02/how-central-eastern-europe-is-transforming-from-outsourcing-toa-real-tech-hub/2/ (11.04.14).

Vanaelst, I., Clarysse, B., Wright, M., Lockett, A. Moray, N. and S'Jegers, R. (2006). Entrepreneurial team development in academic spinouts: An examination of team heterogeneity. Entrepreneurship Theory and Practice, 30, 249-271.

Wooldridge, A. (2009). Global Heroes. Special Report. The Economist. March 12.

Yin, R. (2003). Case-Study Research Design \& Methods. California: Sage.

Zimmerman, M.A. and Zeitz, G.J. (2002). Beyond survival: Achieving new venture growth by building legitimacy. Academy of Management Review, 27 , 414-431. 